\title{
MARKETING EXPENDITURE IMPACT ON BANK'S FINANCIAL PERFORMANCE: A CASE STUDY ON KUWAITI BANKS
}

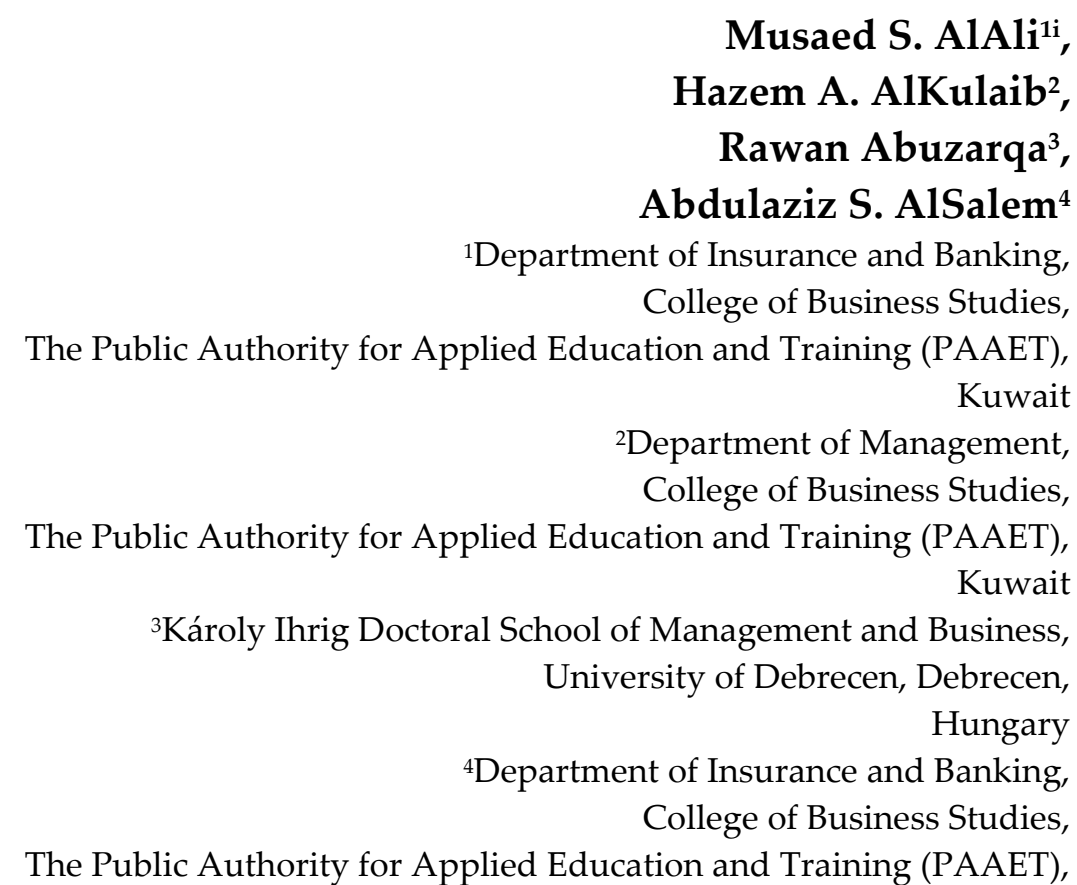

Kuwait

\begin{abstract}
:
Marketing personnel are always under pressure to justify their marketing strategies expenses to bank top management and shareholders. This study aims to provide some justification for their expenses by linking it to the financial performance of the firm. Using the data of ten Kuwaiti banks that are listed at Kuwait stock exchange (KSE) over the period spanning from 2008 to 2018, results show that there is a statistically significant direct relation between marketing expenditure and the financial performance of banks in Kuwait. In addition, results show that both bank size and assets per employee also have a direct relation with bank performance.
\end{abstract}

JEL: G21; G24; G10

Keywords: marketing expenditure, Kuwaiti banks, financial performance, return on assets (ROA)

i Correspondence: email ms.alali@paaet.edu.kw 


\section{Introduction}

The need to gauge the marketing expenditure impact on bank's financial performance has been intensified as banks feel increasing pressure to justify their marketing expenditures to their stakeholders (Gruca and Rego 2005; Rust et al., 2004). As a result, growing pressure on marketing practitioners and researchers is accumulated to clarify the linkage between marketing expenditure and bank's financial performance. While there were many attempts by researchers to examine the effect of marketing on the financial performance of firms, these researches showed conflicted results.

Shah et al. (2009) evaluated the advertising effect on sales of consumer goods firms listed in Karachi Stock Exchange of Pakistan over the period 2004 to 2007 and found that there was a direct relation between them, and that advertisement makes valuable contributions to the value of the firms. Aliata et al. (2012) examined the nature and influence of bank's promotional strategies on its performance. Using different marketing strategies such as advertising, personal selling, sales promotion, publicity, direct marketing and viral marketing and their effect on both sales and profit. Results showed positive relationship between promotional strategies and performance. They also added that bank adopting different promotional and marketing strategies lead to diverse levels of growth. Different levels of growth may lead to banks having different financial performance parameters based on their marketing orientation. Mullineaux and Pyles (2010) studied the effect of U.S. banks investments in advertising and promotion on their performance in the areas of profits and market share. Using the data for the period expanding from 2002 to 2006, they concluded that bank profits and market share increased significantly with increased spending on advertising and promotion. Acar and Temiz (2017) studied the effect of marketing expenditure on the financial performance of 51 Turkish banks over the period 2007 to 2015. Results revealed that marketing expenditure showed a direct effect on the financial performance of banks. Amoako and Dartey- Baah (2012) examined the influence of strategic marketing on the profitability of banks in Ghana. The research showed that strategic marketing had an impact on profitability. Marketing is an ongoing process, according to Abdel-Khalik (1975) when studying the effect of marketing on sales in different industries, namely, food, drug, cosmetics, soap, cleansers, tobacco and auto, found that advertisement showed a cumulative decay effect on sales.

On the opposite side, Upadhyay and Sivakumar (2015) studied the effect of marketing strategies on the financial performance of banks in India. Using the data of 56 banks over the period 2004 to 2012, they did not find any significant relation between implementing marketing strategies that included advertisements and promotions on the financial performance of the banks. Heiens and Pleshko (2011) studied the relationship between marketing orientation and profitability. The study found that less aggressive and less costly approaches to market orientation and marketing strategy, actually pay off in terms of objectively measured ROA. The study also found an inverse relationship between aggressive market orientation and profitability. Rodríguez and Berrio (2011) 
attempted to study the impact of marketing orientation on financial performance in Micro Small and Medium Enterprises (MSME's). Research results showed no statistically significant impact of marketing orientation on financial performance.

The research is set to examine the following hypotheses:

1) $\mathrm{H}_{0}$ : There is no statistically significant relation between number of ATM machines (X1) and bank financial performance.

2) $\mathrm{H}_{0}$ : There is no statistically significant relation between number of bank branches (X2) and bank financial performance.

3) $\mathrm{H}_{0}$ : There is no statistically significant relation between number of number of staff (X3) and bank financial performance.

4) $\mathrm{H}_{0}$ : There is no statistically significant relation between advertisement expenditure (X4) and bank financial performance.

5) $\mathrm{H}_{0}$ : There is no statistically significant relation between bank total assets (X5) and bank financial performance.

6) $\mathrm{H}_{0}$ : There is no statistically significant relation between assets per employees (X6) and bank financial performance.

\section{Research Methodology}

This study mainly attempts to examine marketing expenditure effect on the financial performance of ten banks listed at Kuwait stock exchange (KSE) over the period 2008 to 2018. A panel data is used to evaluate that relation where return on assets (ROA) is set as dependent variable and number of ATM machines, number of bank branches, number of staff, advertisement expenses, bank's total assets, and assets per employees are set as independent variables. In evaluating the effect of these factors on the financial performance of banks, panel OLS regression is used as set in formula 1.

$$
R O A_{t}=\alpha+\beta_{1} \ln X 1_{t}+\beta_{2} \ln X 2_{t}+\beta_{3} \ln X 3_{t}+\beta_{4} \ln X 4_{t}+\beta_{5} \ln X 5_{t}+\beta_{6} \ln X 6_{t}+\varepsilon
$$

Where return on assets (ROA) is the proxy of financial performance, which is used as dependent variable, $\mathrm{X} 1, \mathrm{X} 2, \mathrm{X} 3, \mathrm{X} 4, \mathrm{X} 5, \mathrm{X} 6$ are the natural logarithm number of ATM machines, the natural logarithm of number of bank branches, the natural logarithm of number of staff, the natural logarithm of advertisement expenses, the natural logarithm of bank's total assets, and the natural logarithm of assets per employees respectively that are used as independent variables.

\section{Data and Empirical Results}

The aim of this study is to evaluate the impact of marketing expenditure on bank's return on assets (ROA) as a proxy of financial performance. This research is based on the financial data of ten Kuwaiti banks over the period 2008-2018. The data for this research were obtained from banks annual reports. 
Descriptive analysis is presented in Table 1 , from the table, it can be seen that Kuwaiti banks achieved a mean return on assets (ROA) of $0.80 \%$ over the study period. Banks in Kuwait had an average ATM machines of 139 and 39 branches per bank. Kuwaiti banks spend almost $1.64 \%$ worth of their total assets on marketing their products. Using kurtosis and skewness results to identify distribution normality of the data, it can be seen that both of them fall within the acceptable range of normal distribution since the data fall between \pm 3 and \pm 10 for skewness and kurtosis respectively (Klein, 1998).

Table 1: Descriptive Analysis

\begin{tabular}{lccccccc} 
& ROA & X1 & X2 & X3 & X4 & X5 & X6 \\
\hline Mean & $0.80 \%$ & 138.78 & 38.79 & 1152.64 & 104.07 & 6346.35 & 4.86 \\
\hline Standard Error & $0.11 \%$ & 10.14 & 1.77 & 66.94 & 11.66 & 606.26 & 0.24 \\
\hline Median & $0.97 \%$ & 114.50 & 37.00 & 823.50 & 50.04 & 4109.64 & 4.15 \\
\hline Standard Deviation & $1.17 \%$ & 103.45 & 18.09 & 682.67 & 118.87 & 6182.61 & 2.49 \\
\hline Kurtosis & 8.36 & 9.53 & -1.15 & -0.53 & 2.39 & 2.39 & 0.91 \\
\hline Skewness & -2.16 & 2.46 & 0.09 & 0.91 & 1.84 & 1.73 & 1.13 \\
\hline Count & 104 & 104 & 104 & 104 & 104 & 104 & 104 \\
\hline
\end{tabular}

The panel OLS regression output is presented in table 2, from the table it can be seen that the variables used in this study were only able to explain $17.7 \%$ of the variation in return on assets (ROA) but never the less the model can be labeled as a "good fit" since Sig F was less than 0.05. By looking at the explanatory variables, it can be seen that out of the six variables under study only three showed statistically significant effect on banks profitability. Marketing and advertisement expenditure showed statistically significant positive relation with bank's financial performance which supports Mullineaux and Pyles (2010) findings. Bank's size also showed a statistically significant positive relation with bank's profitability which was in line with AlAli (2019) findings. According to AlAli (2020), having high assets per employee would lead to a higher profitability, to a certain extent. Results from this study supports this finding by showing statistically significant positive relation between assets per employee and bank's profitability.

Table 2: OLS Regression output

\begin{tabular}{|c|c|c|c|c|}
\hline R Square & 0.2249 & & F & Significance $F$ \\
\hline Adjusted R Square & 0.1770 & & 4.6922 & 0.00031 \\
\hline Standard Error & 0.0106 & & & \\
\hline \multirow[t]{2}{*}{ Observations } & 104 & & & \\
\hline & Coefficients & t Stat & P-value & \\
\hline Intercept & -0.072 & $-2.454^{* *}$ & 0.016 & \\
\hline $\mathrm{X} 1$ & -0.005 & -1.361 & 0.177 & \\
\hline $\mathrm{X} 2$ & -0.002 & -0.296 & 0.768 & \\
\hline X3 & -0.009 & -0.940 & 0.350 & \\
\hline$X 4$ & 0.010 & $2.731^{* * *}$ & 0.008 & \\
\hline$X 5$ & 0.026 & $2.974^{* * *}$ & 0.004 & \\
\hline $\mathrm{X} 6$ & 0.002 & $1.263^{*}$ & 0.081 & \\
\hline
\end{tabular}




\section{Conclusion}

With increasing pressure by stakeholders on marketing personnel in banks to justify their marketing expenses. This study was set to shed some light on the effect of marketing expenditure on the financial performance of Kuwaiti banks. Using the data of ten Kuwaiti banks over the period 2008 to 2018, results showed that marketing expenditure had positive effect on the financial performance of banks in Kuwait. The results of this study would justify the marketing expenses in banks but to a certain extent, balancing the profit margin of marketing expenditure is a very hard task since high cost intense marketing strategies might yield similar result as less expensive less intense strategies as concluded by Heiens and Pleshko (2011).

\section{Conflict of Interest Statement}

The authors declare no conflicts of interests.

\section{About the Authors}

Musaed S. AlAli holds a bachelor degree in finance and banking from Kuwait University (1993), master in business administration (MBA) from Middle Tennessee State University (1995), and a doctoral of philosophy (PhD) from RMIT University in Australia (2016). Dr. AlAli worked in a number of investment and banking institutions for 14 years as a senior treasury dealer before joining PAAET in 2009. His main areas of interest are financial management, financial analysis and financial economics.

Hazem A. AlKulaib holds a bachelor degree in marketing from Eastern Washington University (1996) and master degree in marketing from University of Exeter (2009). His main areas of interest are consumer behavior and pricing strategies.

Rawan Abuzarqa is a PhD candidate at Debrecen University, she holds a master's degree in business administration (MBA) and a bachelor degree in accounting. Her main areas of interest are bank risk management, financial management, and financial economics.

Abdulaziz S. AlSalem holds a bachelor degree in finance from Kuwait University and a master's degree in risk management and insurance from City University London. His main areas of interest are risk management and insurance.

\section{References}

Abdel-Khalik, A. R. (1975). Advertising effectiveness and accounting policy, The Accounting Review, 50(4), 657-670.

Acar. M. and Temiz, H. (2017). Advertising effectiveness on financial performance of banking sector: Turkey case, International Journal of Bank Marketing, 35(4), 649-661. https://doi.org/10.1108/IJBM-03-2016-0036 
AlAli, M. S. (2019). Exploring the Internal Determinants of Kuwaiti Banking Sector Profitability, International Journal of Economics and Financial Management, 4(3), 8084.

AlAli, M. S. (2020). Staff Efficiency Effects on Financial Performance: A Case Study on Kuwaiti Banks, International Journal of Business and Applied Social Science, 6(8), 5963. DOI: $10.33642 /$ ijbass.v6n8p8

Aliata, V. L., Odondo, A. J., Aila, F. O., Ojera, P. B., Abong'o, B. E., and Odera, O. (2012). Influence of promotional strategies on banks performance, International Journal of Business, Humanities and Technology, 2(5), 169-178.

Amoako, G. K., and Dartey-Baah, K. (2012). An analysis of the impact of strategic marketing on profitability of rural banks-A case study of Dangme Bank,

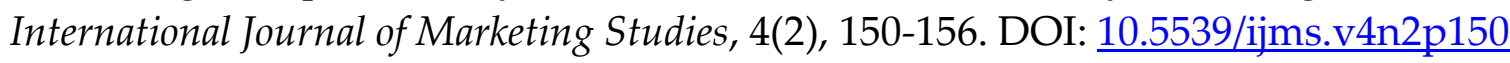

Gruca, T. S., and Rego. L. L. (2005). Customer Satisfaction, Cash Flow, and Shareholder Value, Journal of Marketing, 69, 115-130.

Heiens, R. A., and Pleshko, L. P. (2011). A contingency theory approach to market orientation and related marketing strategy concepts: Does fit relate to profit performance?, Management $\mathcal{E}$ Marketing, 6(1), 19-34.

Klein, A. (1998). Firm performance and board committee structure, The Journal of Law and Economics, 41(1), 275-304.

Mullineaux, D. J. and Pyles, M. K. (2010). Bank marketing investments and bank performance, Journal of Financial Economic Policy, 2(4), 326-345. https://doi.org/10.1108/17576381011100856

Rodríguez, R. A. V., and Berrio, S. P. R. (2011). The impact of market orientation on the financial performance of Micro Small and Medium Enterprises (MSMEs) in Bogota, Management notebooks Valley College, 27(46), 131-141.

Rust, R. T., T. Ambler, G. S. Carpenter, Kumar, V. and Srivastava, R. K. (2004). Measuring Marketing Productivity: Current Knowledge and Future Directions, Journal of Marketing, 68, 76-89.

Shah, S. Z. A., Stark, A. W. and Akbar, S. (2009). The value relevance of major media advertising expenditures: some UK evidence, The International Journal of Accounting, 44(2), 187-206.

Upadhyay, A. and Sivakumar, N. (2015). Impact of Marketing Orientation on Financial Performance of Banks in India, International Journal of Banking, Risk and Insurance, 3(1), 36-45. 

distribute, transmit or adapt the article content, providing a proper, prominent and unambiguous attribution to the authors in a manner that makes clear that the materials are being reused under permission of a Creative Commons License. Views, opinions and conclusions expressed in this research article are views, opinions and conclusions of the author(s). Open Access Publishing Group and European Journal of Economic and Financial Research shall not be responsible or answerable for any loss, damage or liability caused in relation to/arising out of conflict of interests, copyright violations and inappropriate or inaccurate use of any kind content related or integrated on the research work. All the published works are meeting the Open Access Publishing requirements and can be freely accessed, shared, modified, distributed and used in educational, commercial and non-commercial purposes under a Creative Commons Attribution 4.0 International License (CC BY 4.0). 